Ann. rheum. Dis. (1963), 22, 440.

\title{
HAEMATOLOGICAL SIDE-EFFECTS OF SOME ANTI-RHEUMATIC DRUGS*
}

\author{
BY
}

H. O. NIEWEG, H. G. D. BOUMA, K. DE VRIES, AND A. JANSZ

From the Department of Medicine and the Department of Bacteriology and Serology, University of Groningen, The Netherlands

The Study Group on Blood Dyscrasias of the American Medical Association Council on Drugs has made a list of drugs, which have been shown by direct or circumstantial evidence to be associated with blood dyscrasias (Erslev and Wintrobe, 1962; A.M.A., 1962). From this list those drugs were selected which are used in the treatment of arthritis and allied conditions, and the following observations are presented because they may be of some practical value if confirmed by other workers.

Table I gives their generic names and the various types of blood disorder which they may cause by various mechanisms.

TABLE I

DRUGS SHOWN BY DIRECT OR CIRCUMSTANTIAL EVIDENCE TO BE ASSOCIATED WITH BLOOD DYSCRASIAS

\begin{tabular}{|c|c|c|c|c|}
\hline Drug & $\begin{array}{l}\text { Haemo- } \\
\text { lytic } \\
\text { Anaemia }\end{array}$ & $\begin{array}{l}\text { Aplastic } \\
\text { Anaemia } \\
\text { with } \\
\text { Pancyto- } \\
\text { penia }\end{array}$ & $\begin{array}{c}\text { Thrombo- } \\
\text { cyto- } \\
\text { penia }\end{array}$ & $\begin{array}{c}\text { Agranulo- } \\
\text { cytosis } \\
\text { Leuko- } \\
\text { penia }\end{array}$ \\
\hline Amidopyrine .. & $x$ & - & - & $\times$ \\
\hline Colchicine $\quad$. & 一 & $\times$ & $\times$ & $x$ \\
\hline Gold $\quad \ldots \quad \ldots$ & - & $x$ & $\times$ & $x$ \\
\hline Mepacrine & 一 & $\times$ & $x$ & $x$ \\
\hline Meprobamate . . & - & $\times$ & $\times$ & $x$ \\
\hline Phenacetin & $\times$ & - & - & - \\
\hline Phenylbutazone & 一 & $\times$ & $x$ & $\times$ \\
\hline Probenecid & $\times$ & - & 一 & 一 \\
\hline
\end{tabular}

Decreased retraction caused by acetylsalicylic acid.

ToxICITY.-Colchicine inhibits mitosis. The bone marrow is characterized by a high frequency of cell division, so that it is not surprising that colchicine may decrease the number of circulating blood

* Paper given at a joint meeting of the Nederlandse Vereniging van Rheumatologen and the Heberden Society at Groningen, the Netherlands, on May 18, 1963. cells by retarding their production. A decrease in the circulating blood cells can also be due to their premature destruction. An example is the haemolytic anaemia induced by doses of phenacetin large enough to be toxic.

IDIOSYNCRASY.-Patients who have an enzymatic defect in their red cells, a deficiency of glucose-6phosphate dehydrogenase, are known to be especially susceptible to haemolytic reactions to drugs like phenacetin and probenecid even at the first exposure. This type of idiosyncrasy differs from the individuat hypersensitivity caused by allergic and immunological mechanisms, for in the latter case previous exposure is necessary for sensitization.

Allergy.-A well-known example of an allergic reaction is the thrombocytopenic purpura due to apronal (Sedormid). In a classical series of investigations Ackroyd (1960) has shown that this drug may induce the formation of antibodies which, in the presence of the drug, agglutinate platelets in vitro. Apparently the drug acts as a hapten which combines with a platelet constituent as a carrier. A similar mechanism is probably responsible for the amidopyrine-induced agranulocytosis in which we again deal with individual hypersensitivity. According to Meiers, Gehrmann, and Gahlen, 1963), antibodies have also been found in a patient with a blood disorder due to phenylbutazone. As far as we know the mechanism responsible for the blood dyscrasias associated with the other drugs in Table I has not been established.

\section{Personal Experience}

During the last 18 months four patients were seen by us in whom splenectomy was performed at our request. In each case the diagnosis of idiopathic thrombocytopenic purpura (ITP) was made because we could find no evidence of a disease involving 
the spleen or the bone marrow which might produce thrombocytopenia. There was no history of a preceding infection. These patients were asked about exposure to drugs and other chemicals. The only point emerging was that all of them sometimes took a tablet of acetylsalicylic acid alone or in combination with phenacetin and caffeine, as most people do on occasion. After an initial increase in the platelet count after the operation, a relapse of the purpura occurred in three of the four patients, although it is usually said that splenectomy is an effective procedure in at least 75 per cent. of cases of ITP. Disturbed by this experience we reconsidered the diagnosis in our patients. An unusual feature was the absence of the platelet antibodies which are often associated with ITP, and we found that $\mathrm{Cr}^{51}$-tagged platelets were rapidly removed from the circulation. Our immunological procedures included the more orthodox antiglobulin consumption test both direct and indirect, and a modification of the Schultz-Dale test developed by Jansz (1960) for the demonstration of platelet antibodies. Unlike the immunologist, the pathologist found signs of immunological activity, because there was marked hyperplasia of the lymphoid follicles in the spleen of two of these patients.

It was noted that all four patients had taken acetylsalicylic acid, but we had considered it improbable that this drug could be responsible for the thrombocytopenia.

The American Study Group on Blood Dyscrasias cited acetylsalicylic acid as an example of a drug "innocent of the potential for haemato-toxicity", and in a recent review of analgesics in "Today's Drugs" in the British Medical Journal (1963), thrombocytopenia is not mentioned as one of the side-effects of acetylsalicylic acid.

To determine if we had been dealing with allergy to acetylsalicylic acid in these four cases, we used three techniques adapted by our group for the detection of drug antibodies.

(1) The first method is a passive haemagglutination procedure, in which BDB (bis-diazotized benzidine) is used for coupling the drug to red cells (Stavitsky and Arquilla, 1955). This test gives positive results in sera from patients suspected of hypersensitivity to penicillin, PAS, streptomycin, sulphonamide, amidopyrine, and ACTH. Heine and Friedman (1962) also used this procedure with success for finding a drug antibody in a case of the hydralazine syndrome. This technique gave positive results with acetylsalicylic acid in the four patients originally considered to have ITP.

(2) The second method is a modification of the classical Schultz-Dale test. Guinea-pigs were given 4 gr. acetylsalicylic acid three times in 18 hours and were then killed. The uterus horn was put in an oxygenated balanced salt solution and attached to an apparatus for recording contractions. The muscle strip contained some antigen. Serum samples to be tested for antibodies against acetylsalicylic acid were added to the fluid. The occurrence of an antigen-antibody reaction is indicated by contraction of the muscle strip. Suitable controls are of course necessary in this biological assay system. This technique also gave positive results in the four splenectomized patients who had used acetylsalicylic acid.

(3) A third method was adapted from the reports of Ackroyd, who demonstrated that, in thrombocytopenia due to drug allergy, the addition of the drug to blood or plasma may impair the process of clot retraction.

In our laboratory we use a quantitative procedure with diluted plasma, to which thrombin is added. The length of the clot is determined at various intervals, the percentage decrease being the parameter used in this test (Figure).

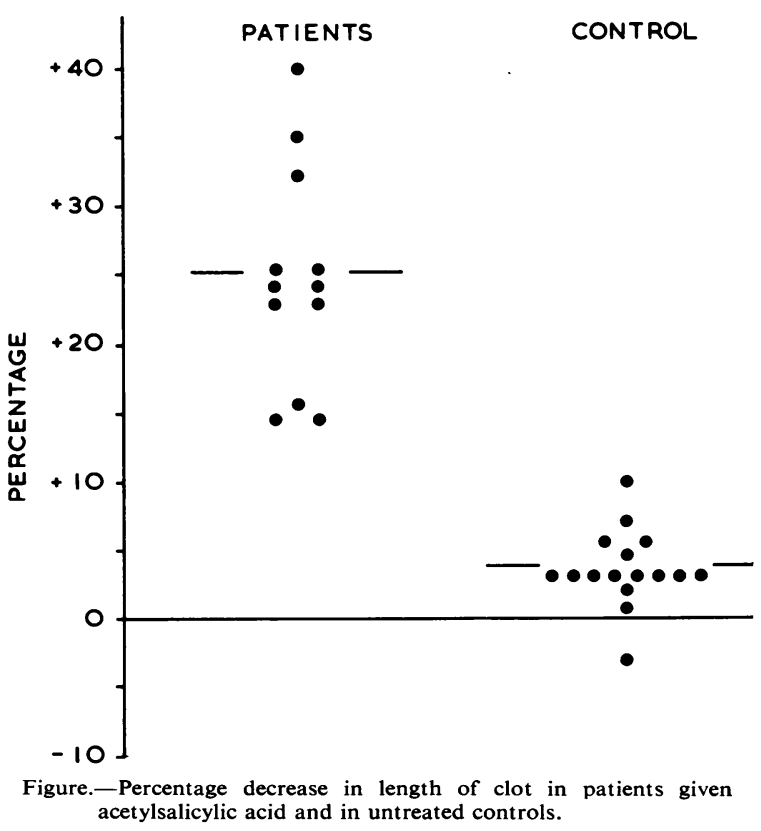

The addition of acetylsalicylic acid causes a significant decrease in the retraction in patients but not control subjects. The impairment of clot retraction by acetylsalicylic acid also occurs, when the system consists of normal platelets and plateletfree plasma from the patient. These observations 
suggest that a factor is present in the plasma which inhibits platelet function in the presence of acetylsalicylic acid and links the drug-induced antibodies and the thrombocytopenia.

We should have liked to have given a test dose to a patient to see if thrombocytopenia developed again, but hesitated to do this. One of the patients, however, performed the experiment of his own accord, and was found to have an extremely variable platelet level. One week the platelet count might be normal, and the next week it might be down to 5,000 . It was found that the patient took APC tablets whenever he felt tense and that periods of emotional stress were associated with the thrombocytopenic episodes. This observation can, however, hardly be considered as a controlled experiment.

It should be mentioned that the patients who had a relapse after splenectomy did not have another episode of thrombocytopenic purpura after they had been advised not to use acetylsalicylic acid.

Table II summarizes the data obtained on the four original patients and on those seen subsequently. In eight patients the platelet lifespan could be determined during the attack of thrombocytopenia, when we found rapid removal of the tagged platelets from the circulation. The BDBtest was positive in eight out of eleven patients, and the Schultz-Dale in eight out of ten. Negative results were found, especially in the patients who had received large amounts of corticosteroids. The inhibition of clot retraction thus appears to be a sensitive test.

TABLE II

DATA OF ELEVEN PATIENTS WITH ACETYLSALICYLIC ACID-INDUCED THROMBOCYTOPENIC PURPURA

\begin{tabular}{c|c|c|c|c}
\hline $\begin{array}{c}\text { Case } \\
\text { No }\end{array}$ & $\begin{array}{c}\text { Inhibition } \\
\text { Retraction }\end{array}$ & $\begin{array}{c}\text { Positive } \\
\text { Haem- } \\
\text { agglutina- } \\
\text { tion }\end{array}$ & $\begin{array}{c}\text { Schultz- } \\
\text { Dale }\end{array}$ & $\begin{array}{c}\text { Platelet } \\
\text { Life } \\
\text { Span } \\
\text { (days) }\end{array}$ \\
\hline 1 & + & $1 / 32$ & + & 1 \\
2 & + & $1 / 256$ & + & 1 \\
3 & + & $1 / 256$ & + & 1 \\
4 & + & $1 / 32$ & ++ & $<1$ \\
\hline 5 & + & $1 / 8$ & - & 2 \\
6 & + & + & + & 1 \\
7 & + & $1 / 1,024$ & ++ & 1 \\
8 & + & $1 / 256$ & + & 1 \\
9 & + & $1 / 64$ & + & \\
11 & + & + & $1 /$ & \\
\hline
\end{tabular}

Cases 1, 2, 3, and 4 were splenectomized. Cases 5, 6, 7, 10, and 11 had been treated with corticosteroids before the serum was obtained.

The diagnostic difficulties in thrombocytopenic purpura are illustrated by Case 9 , who was treated for Hodgkin's disease with chlorambucil, a cystostatic drug known to be toxic for bone marrow. A severe thrombocytopenia rapidly developed, although he had taken a relatively small amount of the drug, which usually causes a gradual, slow decrease in the platelets. The thrombocytopenia was found to be due to platelet destruction and not to inhibition of platelet production, the bone marrow being highly cellular. We found antibodies against acetylsalicylic acid, and the purpura was presumably due to hypersensitivity to this drug. The same applied to Case 7, who had been treated with quinidine, and whose serum did not contain antibodies against quinidine.

ChLOROQUINE OR HydroXYCHLOROQUINE.-These drugs are not included in the list of the American study group. Ten patients taking them were found to have thrombocytopenia. One, who had agranulocytosis as well, had taken both chloroquine and phenylbutazone, and died from cerebral haemorrhage, but we do not know which of the two drugs was responsible for this.

In this group of patients the immunological data are less extensive because the study goes back to an earlier period (Table III).

\section{TABLE III}

DATA OF SEVEN PATIENTS WITH THROMBOCYTOPENIA ASSOCIATED WITH CHLOROQUINE AND HYDROXYCHLOROQUINE

\begin{tabular}{c|c|c|c}
\hline $\begin{array}{c}\text { Case } \\
\text { No. }\end{array}$ & $\begin{array}{c}\text { Positive } \\
\text { Haemagglutination }\end{array}$ & $\begin{array}{c}\text { Schultz- } \\
\text { Dale }\end{array}$ & $\begin{array}{c}\text { Platelet } \\
\text { Life Span } \\
\text { (days) }\end{array}$ \\
\hline 1 & $1: \overline{8,192}$ & + & $<1$ \\
2 & - & + & $<1$ \\
3 & $1: 128 ; 1: 512$ & - & $<1$ \\
4 & $1: 10$ & + & $<1$ \\
5 & - & + & 10 \\
6 & 7 & - & 9 \\
\hline
\end{tabular}

Case 4 had also had phenylbutazone.

We found a positive haemagglutination test with chloroquine in three out of the five cases investigated by this technique.

The Schultz-Dale test was positive in three of the four cases in which it was performed.

The clot retraction procedure could not be used because chloroquine causes toxic inhibition of retraction with normal platelets suspended in normal plasma.

In a series of in vivo survival studies, $\mathrm{Cr}^{51}$-labelled platelets exposed to antibody containing plasma and plasma of a normal subject who was given chloroquine were rapidly removed from the circulation in two separate experiments.

In some of these patients thrombocytopenia is due to destruction of the circulating platelets. The 
mechanism is similar to thrombocytopenia induced by acetylsalicylic acid. In other patients, however, the platelet life span was normal, even though the thrombocytopenia did not improve and the drug was continued during the period of this study. In these patients the thrombocytopenia must be due to impaired production of platelets, probably because of allergy, since in two we found antibodies against chloroquine. We must therefore assure that thrombocytopenia due to drug allergy may be classified into two types:

(1) The classical type (studied by Ackroyd and others) in which an antibody with affinity for the drug-platelet complex has been demonstrated and in which $\mathrm{Cr}^{51}$-tagged platelets were rapidly removed from the circulation.

(2) Impaired bone marrow function induced by drugs which is not necessarily toxic in origin, but may be allergic. We found this allergic mechanism also in a case of thrombocytopenia due to phenobarbitone.

Many workers may find it hard to accept our main conclusion that allergy to acetylsalicylic acid is not such a rare cause of thrombocytopenia as the reports of D'Eshougues and his colleagues (1959, 1961) suggest.

\section{Summary}

In a clinical and immunological study the authors obtained evidence indicating that thrombocytopenic purpura may be due to allergic hypersensitivity to acetylsalicylic acid, chloroquine, or hydroxychloroquine.

\section{REFERENCES}

Ackroyd, J. F. (1960). In "Lectures on Haematology", ed. F. G. J. Hayhoe, p. 217. University Press, Cambridge.

American Medical Association: Study Group on Blood Dyscrasias, Committee on Adverse Reactions, Council on Drugs (1962). Semi-annual Tabulation of Reports compiled by the Registry on Blood Dyscrasias, vol. 6, no. 2.

Brit. med. J. (1963), 1, 317.
D'Eshougues, J. R., Griguer, P., Smadja, A., and Bensaid, J. (1961). Nouv. Rev. franç. Hemat., 1, 609.

$\longrightarrow,-$ and Tadei, A. (1959). Bull. Soc. méd. Hôp. Paris, 75, 862.

Erslev, A. J., and Wintrobe, M. M. (1962). J. Amer. med. Ass., 181, 114.

Heine, W. I., and Friedman, H. (1962). I Ibid., 182, 726. Jansz, A. (1960). Thesis, Groningen.

Meiers, H. G., Gehrmann, G., and Gahlen, W. (1963). Dtsch. med. Wschr., 88, 580.

Stavitsky, A. B., and Arquilla, E. R. (1955). J. Immunol., 74, 306.

\section{Addendum}

Since this paper was presented, the authors have seen nine more patients with acetylsalicylic acidinduced thrombocytopenic purpura.

Further serological studies have shown that complement-fixation occurs when fresh guinea-pig serum is added to a system consisting of platelets, acetylsalicylic acid, and patient's serum.

A provocative test was performed in one patient who showed a rapid fall in the platelet level from 120,000 to 20,000 per c.mm. while taking $3 \mathrm{~g}$. acetylsalicylic acid per day. 24 hours after the drug was discontinued the platelet count had risen to 100,000 .

Effets secondaires hématologiques de certains produits anti-rhumatismaux

\section{RÉSUMÉ}

Des études cliniques et immunologiques ont fourni aux auteurs des données indiquant que le purpura thrombocytopénique peut être dû à l'hypersensibilité allergique a l'acide acétylsalicylique, à la chloroquine ou à l'hydroxychloroquine.

\section{Efectos secundarios hematológicos de ciertos productos anti-reumáticos \\ SUMARIO}

De un estudio clínico e inmunológico los autores obtuvieron evidencia de que la púrpura trombocitopénica puede ser debida a una hipersensibilidad alérgica al ácido salicílico, 1 cloroquina o la hidroxicloroquina. 